\title{
The nuclear $16-\mathrm{kD}$ protein methylation increases in the early period of liver regeneration in a hepatectomized rat
}

\author{
Kyounghwa Lee ${ }^{1 *}$, Kyung-Mi Lee ${ }^{1 *}$, \\ Tae Jin Kim ${ }^{1}$, Meyoung Kon Kim ${ }^{1}$, \\ Jong Seol $\mathrm{Han}^{2}$, Yoon Sik Hong ${ }^{3}$, \\ Gil Hong Park ${ }^{1}$ and Kyo Won Lee $e^{2,4}$
}

${ }^{1}$ Department of Biochemistry

College of Medicine, Korea University

Seoul 136-705, Korea

${ }^{2}$ Department of Obstetrics and Gynecology

Kangbuk Samsung Hospital, School of Medicine

SungKyunKwan University, Seoul 110-746, Korea

${ }^{3}$ Department of Emergency Medicine

College of Medicine, Korea University

Seoul 136-705, Korea

${ }^{4}$ Coressponding author: Tel, 82-02-2001-2193;

Fax, 82-02-2001-2187; E-mail, kw4773@hanmail.net

*Theses authors contributed equally to this work.

Accepted 6 December 2004

Abbreviations: ADMA, $N^{G} N^{G}$-dimethyl(asymmetric)arginine; AdoMet, S-adenosyl-L-methionine; G-protein, GTP-binding protein; GTP, guanosine triphosphate; hnRNP, heterogeneous nuclear ribonucleoprotein; MMA, $\mathrm{N}^{G}$-monomethylarginine; PRMT, arginine methyltransferase; SDMA, $N^{G} N^{\prime G}$-dimethyl(symmetric)arginine

\begin{abstract}
Methylation events play a critical role in various cellular processes including regulation of gene transcription and proliferation. We observed that methyltransferase activity underwent time-dependent changes in the cytosol of the rat hepatocytes upon partial hepatectomy. However, any change in the methylation of nuclear proteins is not clear during hepatocyte proliferation. The nuclear fraction possesses basal level of methyltransferase to catalyze methylation of several proteins ranging from 7 to $70 \mathrm{kD}$ prior to any hepatecmony. The specific p16 (16 kD) band was transiently and heavily methylated post 1 day hepatectomy, and then became nondetectable, but not in the control liver. Methylation of $p 16$ band was completely inhibited by exogenously added histones, particularly 2AS, 1 , $2 A$ and $2 B$ subtypes. The methylated p16 protein remains stable in either acid or alkali- induced demethylation conditions, indicating that
\end{abstract}

methylation is not likely to occur on isoaspartyl or C-terminal cysteinyl residues. Exogenous addition of non-hydrolyzable GTP caused a dosedependent suppression of a $p 16$ methylation suggesting that G-proteins might play a role as an endogenous methylation inhibitor in vivo. Taken together, we have identified the proliferation event associated-methylation of the nuclear p16 protein in the hepatocytes undergoing liver regeneration.

Keywords: histone; nuclear methyl acceptors; protein methylation; regenerating rat liver

\section{Introduction}

Methylation has been shown to play important roles in several biological phenomena occurring in prokaryotes as well as eukaryotes. Methylation is one of the major posttranslational or posttranscriptional modifications of macromolecules including protein, RNA and DNA. Protein methylation is found in the residues, arginine, aspartate, glutamate, lysine and C-terminal cysteine, which has been shown to occur in a variety of cellular processes including protein trafficking, protein-protein interaction, and various signal transduction pathways leading to cellular proliferation (Paik and Kim, 1980; McBride and Silver, 2001). Methylation of proteins is catalyzed by highly specific methyltransferases which transfer a methyl group from Sadenosyl-L-methionine (AdoMet) to the guanidino nitrogen of arginine residues, generating $N^{G}$-monomethylarginine (MMA), $\quad N^{G} N^{G}$-dimethyl(asymmetric)arginine (ADMA) and $N^{G} N^{\prime G}$-dimethyl(symmetric)arginine (SDMA) (Paik and Kim, 1980; Gary et al., 1996), or to lysine to produce $\mathrm{N}^{\varepsilon}$-mono-, $\mathrm{N}^{\varepsilon}$-di-, and $\mathrm{N}^{\varepsilon}$-trimethyllysine (Duerre et al., 1977), or to aspartate or glutamate to produce alkali labile ester linkages (Tan et al., 1991), or to C-terminal farnesylated cysteine to produce carboxyl methyl ester (Backlund, 1992).

Proliferation occurs through series of changes in which expression of numerous genes allow progression into the cell cycle. Earlier studies demonstrated that the activity of protein arginine methyltransferase (PRMT) was directly correlated with the degree of proliferation and thus, it was found to be elevated in highly proliferating tissues such as regenerating liver (Kwon et al., 2004), developing fetal brain, rapidly growing hepatomas and continuously dividing HeLa cells (Paik et al., 1975; Paik and Kim, 1980). Indeed, 
a $20-k D a$ protein in the cytosol was found to be a major substrate of methyltransferases activated in proliferating mammalian cells. For example, exponentially growing human cancer cell lines, such as HCT48, HeLa cells, A549, and Hep G2, all showed increased level of methylation in this $20-k D$ protein as compared to their normal counterparts, suggesting that increased methylation may be associated with cellular proliferation and transformation (Park et al., 1997; Gu et al., 1999). In addition, we showed recently that methylation of this cytosolic $20-\mathrm{kDa}$ protein was increased in a more physiologic setting, such as proliferating hepatocytes, due to elevated methyltransferase activity, and that histones were likely to play some regulatory roles in this process (Kwon et al., 2004).

Since our previous studies focused on the methylation of cytosolic proteins in association with hepatocyte proliferation, an immediate question arises if the methylation status changes in the nuclear proteins during the course of cell proliferation. Modification of nuclear proteins is important as it can be closely related to gene transcription, which occurs in the nucleus preceding cell proliferation. Our study now finds that nuclear proteins are also subject to methylation by the methyltransferases activated during the course of liver regeneration. In contrast to the cytosolic fraction, which showed persistent methylation of a $20-\mathrm{kD}$ band up to 7 days following hepatectomy, methylation of nuclear substrates do not show any persistent changes in methylation. Rather their level of methylation was more or less consistent before or after hepatectomy. One exception to this was the appearance of a $16-\mathrm{kD}$ protein heavily methylated 1 day following hepatectomy, which then disappeared rapidly within the next 3 days. Our data describing the characteristics and specificity of the methyltransferases regulating methylation of this $16-\mathrm{kD}$ protein proposes the importance of methylation events in the process of liver regeneration.

\section{Materials and Methods}

\section{Reagents}

S-adenosyl-L-[methyl- $\left.{ }^{3} \mathrm{H}\right]$ methionine $\quad\left(\left[{ }^{3} \mathrm{H}\right]\right.$ AdoMet; 60 $\mathrm{Ci} / \mathrm{mmol}$ ) was purchased from Amersham Pharmacia Biotech Inc. (Buckinghamshire, England). Calf thymus histone II-AS (bulk histone prepared by extraction in $1 \mathrm{M} \mathrm{NaCl}$, precipitation in water, followed by acid extraction, dialysis and lyophilization), myelin basic protein, cytochrome $\mathrm{C}$, alcohol dehydrogenase, $\alpha$-lactalbumin, carbonic anhydrase, $\gamma$ globulin, bovine serum albumin, GTP $\gamma S$ and S-adenosyl-L-homocysteine were purchased from Sigma Chemical Co. (St. Louis, MO). Calf thymus histones $1,2 \mathrm{~A}, 2 \mathrm{~B}, 3$ and 4 were purchased from Roche Applied Science (Mannheim, Germany). Sodium dodecyl sulfate-polyacrylamide gel electrophoresis (SDS-PAGE) reagents and LMW electrophoresis calibration kits were purchased from BioRad Laboratories (Hercules, CA).

\section{Partial hepatectomy}

Median and left lateral lobes (about $70 \%$ of liver) of 6 weeks old Sprague Dawley rats were surgically removed according to the method approved by Institutional Review Board (day 0). Rats were then sacrificed at day $1,3,5,7,14,21$ and 28 following hepatectomy and the remaining (regenerating) liver (right lateral and caudate lobes) was harvested for analysis (Waynforth and Flecknell, 1992). At each time point, three rats were used for analysis.

\section{Preparation of cytosolic extracts}

All procedures were carried out at $4{ }^{\circ} \mathrm{C}$ unless otherwise stated. Harvested liver was cut into small pieces and homogenized in 4 volumes of $0.32 \mathrm{M}$ sucrose containing $5 \mathrm{mM}$ potassium phosphate $(\mathrm{pH} 7.6), 5$ $\mathrm{mM}$ ethylenediaminetetraacetic acid, $1 \mathrm{mM}$ dithiothreitol (DTT), $1 \mathrm{mM}$ 2-mercaptoethanol and $0.5 \mathrm{mM}$ phenylmethylsulfonylfluoride (PMSF). Homogenates were centrifuged at $100,000 \mathrm{~g}$ for $60 \mathrm{~min}$, and the supernatant was used as crude cytosolic extracts which contain endogenous enzymes and substrates of the liver (Gu et al., 1999).

\section{Preparation of nuclear extracts}

$5 \mathrm{~g}$ of rat liver was minced and placed in $10 \mathrm{ml}$ lysis buffer $(0.25 \mathrm{M}$ sucrose, $10 \mathrm{mM} \mathrm{NaCl}, 3 \mathrm{mM} \mathrm{MgCl}$, $1 \mathrm{mM}$ DTT, $0.5 \mathrm{mM}$ PMSF, $10 \mathrm{mM}$ Tris- $\mathrm{HCl}, \mathrm{pH}$ 7.4). The minced liver was homogenized with 5-10 strokes of a serrated Teflon pestle. Homogenate was overlaid on to concentrated sucrose solution (2 M sucrose for control liver or $1.7 \mathrm{M}$ sucrose for regenerating livers, $10 \mathrm{mM} \mathrm{NaCl}, 3 \mathrm{mM} \mathrm{MgCl} 2,1 \mathrm{mM}$ DTT, $0.5 \mathrm{mM}$ PMSF, $10 \mathrm{mM}$ Tris- $\mathrm{HCl}, \mathrm{pH} \mathrm{7.4),} \mathrm{and} \mathrm{centrifuged} \mathrm{at}$ $23,000 \mathrm{rpm}$ at $4^{\circ} \mathrm{C}$ for $30 \mathrm{~min}$ on the SW 28 rotor (Beckman). The pellet was resuspended with lysis buffer and used as nuclei fraction (Spector et al., 1998).

\section{In vitro methylation assay}

Methylation reaction was carried out by adding $5 \mu \mathrm{Ci}$ of $\left[{ }^{3} \mathrm{H}\right.$ ]AdoMet into $50 \mu \mathrm{g}$ of crude extracts of rat liver (nuclei or cytosol) in a total volume of $50 \mu \mathrm{l}$. Where indicated, $20 \mu \mathrm{M}$ of bulk histones (histone II-AS, Sigma) or their individual subtypes, histone 1, 2A, 2B, 3 or 4 , were added to the mixture prior to assay. Alternatively, $20 \mu \mathrm{M}$ of myelin basic protein, cytochrome $\mathrm{C}$, alcohol dehydrogenase, $\alpha$-lactalbumin, car- 
bonic anhydrase, bovine $\chi$ globulin or bovine serum albumin was added to the reaction mixture. S-adenosyl homocysteine, which specifically inhibits AdoMetdependent methylation, was added at $0.8 \mathrm{mM}$ to the reaction mixture to inhibit methyltransferase activity. Reaction was carried out at $37^{\circ} \mathrm{C}$ for $30 \mathrm{~min}$, and stopped by adding $5 \times$ SDS-PAGE sample buffer (Park et al., 1997). Protein concentration was determined according to Bradford method (Bradford, 1976).

Where indicated, the methylation reaction was terminated by addition of $1 \mathrm{mM}$ S-adenosyl-L-homocysteine (a transmethylation inhibitor). The stability of $\left[{ }^{3} \mathrm{H}\right]$ AdoMet incorporation into the nuclear methyl acceptors was tested either by treating extracts with $1 \mathrm{~N}$ $\mathrm{HCl}, \mathrm{pH} \mathrm{3-4,} \mathrm{or} 1 \mathrm{~N} \mathrm{NAOH}, \mathrm{pH} \mathrm{10-11,} \mathrm{for} 60 \mathrm{~min}$ at $37^{\circ} \mathrm{C}$.

\section{Methylation analysis by SDS-PAGE and autoradiography}

The reaction mixture dissolved in SDS-PAGE sample buffer was loaded onto $15 \%$ polyacrylamide gels and run under constant current (20 mA) (Laemmli, 1970). The gel was stained with Coomassie Blue, soaked in Amplify solution (NAMP-100, Amersham), dried and exposed to Hyperfilm ${ }^{\mathrm{TM}}$ MP (Amersham) diagnostic film at $-70^{\circ} \mathrm{C}$ for 7 days. The density of radioactive bands was measured using Fujix-Bio-Imaging Analyzer BAS2500 (Fuji Photo Film).

\section{Results}

Appearance of a novel methylation product in the early period of rat liver regeneration

Upon partial hepatectomy in a rat, the residual hepatic parenchymal stem cells rapidly proliferate and differentiate to reach the normal size of liver within 30 days (Figure 1A, Waynforth and Flecknell, 1992). In our experiment, weight of the remaining liver (right lateral and caudate lobes) increased following partial hepatectomy and reached the normal mass by 28 days. By comparison, weight of right lateral and caudate lobes from age-matched non-hepatectomized mice did not change significantly over time. Similarly, weight of entire liver from non-hepatectomized mice did not change significantly. These data indicate that the remaining liver proliferated and differentiated to restore its original mass.

To examine if regenerating liver cells undergo changes in methylation status, crude cytosolic and nuclear extracts were prepared at various days post hepatectomy and subjected to an in vitro methylation assay. Intriguingly, the densities of regenerating nuclei were found to be lower than those of control nuclei, so regenerating nuclei could be centrifuged down through $1.7 \mathrm{M}$, but not 2.0 M. As shown previously (Kwon et al., 2004), the major band in the cytosol fraction following an in vitro methylation assay $\mathrm{mi}-$ grated at $20 \mathrm{kD}$ (Figure 1). Upon hepatectomy, methylation of this cytosolic 20-kD protein increased more than 5 fold (compare $C$ at day 0 and 1 ). Addition of bulk histone to the assay completely inhibited methylation of the $20-\mathrm{kD}$ protein $(\mathrm{C}+\mathrm{H}$ at day 0 and 1 ), suggesting that histones and this $20-\mathrm{kD}$ protein compete for the same methyltransferase. Interestingly, exogenously added bulk histone also became methylated appearing as a smeary band around $16 \mathrm{kD}$. In contrast to cytosolic fraction, more bands $(\sim 70-k D$, $\sim 24-k D, \sim 18-k D$, and $\sim 7-k D)$ showed basal level of methylation even prior to hepatectomy in the nuclear fraction (Figure 1, see $\mathrm{N}$ at day 0 ). 1 day following hepatectomy, the level of methylation of all three bands remained relatively similar as compared to that before the hepatectomy. However, a new band running around $16 \mathrm{kD}$ was detected as a major methylated protein (compare $\mathrm{N}$ at day 0 and 1). Methylation of a band running at $70 \mathrm{kD}$ appeared to be reduced in this particular gel, however, it was not reproducibly detected in the other experiments. Likewise, other methylated product of about $24-k D, 18-k D$ and $7-k D$ proteins shown as a heavy band in the gel seemed not to be affected by the process of liver regeneration (Figure 1 ).

Since histones are abundant nuclear proteins and also run at $16 \mathrm{kD}$, the $16-\mathrm{kD}$ protein newly appeared

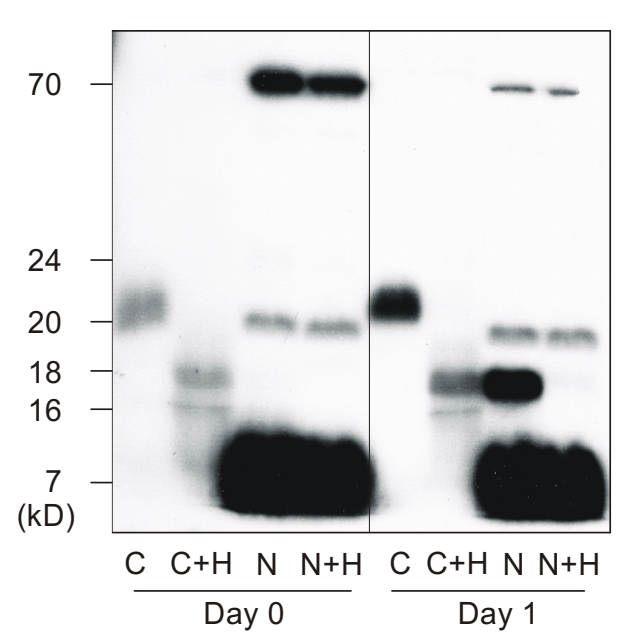

Figure 1. The status of methylation in the regenerating liver following partial hepatectomy. Cytosolic and nuclear extracts were prepared from liver cells prior to or 1 day following partial hepatectomy and subjected to methylation assay as described in the Materials and Method section. Where indicated, $20 \mu \mathrm{M}$ bulk histone was added to the reaction mixture. $\mathrm{C}, \mathrm{N}, \mathrm{H}$ denote cytosol, nucleus, and histones, respectively. 
to be methylated following hepatectomy could likely be histones. Interestingly, however, addition of exogenous bulk histone did not result in or enhance methylation of added histones, but rather blocked methylation of a $16-\mathrm{kD}$ protein (Figure 1). These data suggest that a $16-\mathrm{kD}$ band may not likely be histones. Since histones can compete with a $16-k D$ protein for methylation, methyltransferases responsible for meth-
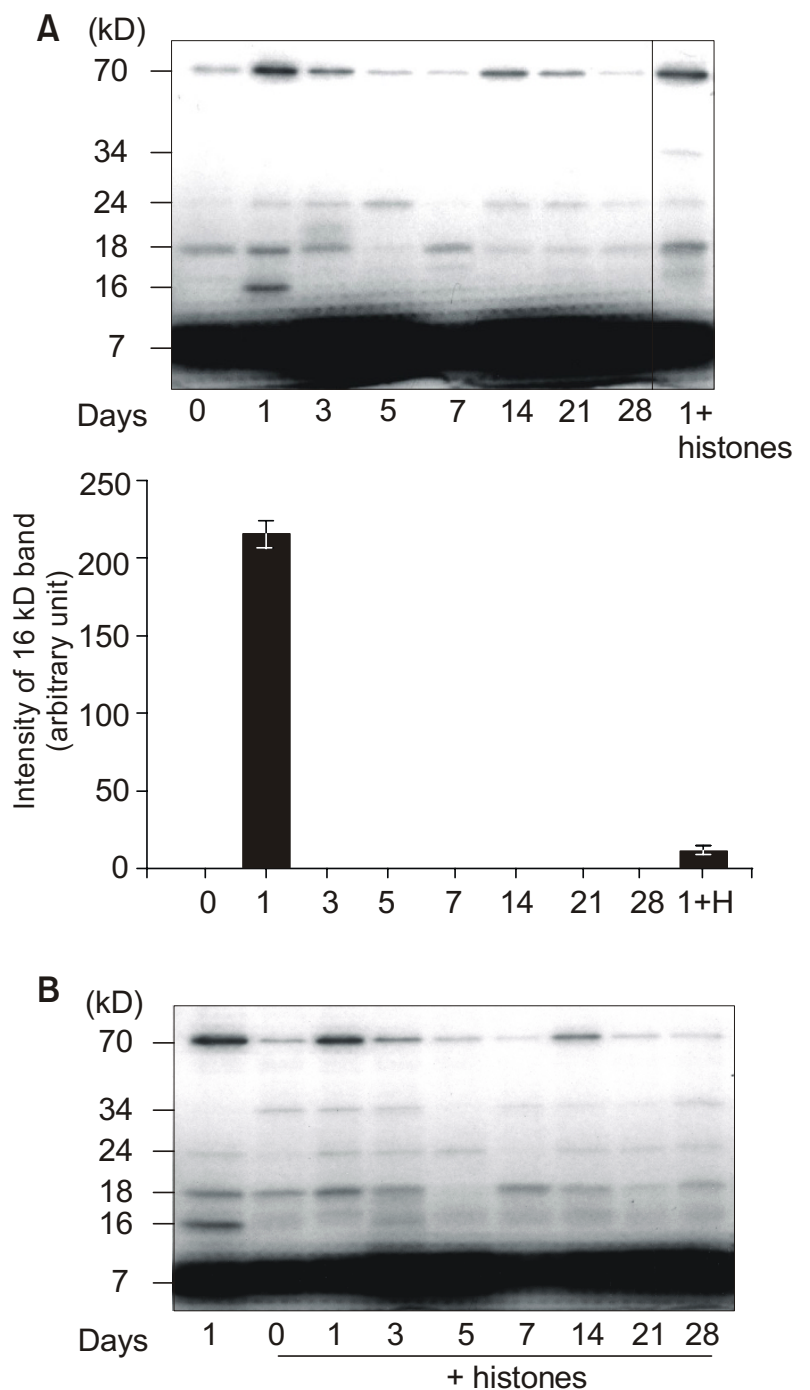

Figure 2. Changes in the methylation status of nuclear proteins in the regenerating liver cells. Nuclear extracts were prepared from rat liver at $0,1,3,5,7,14,21,28$ days following partial hepatectomy and subjected to methylation assay. Where indicated, $20 \mu \mathrm{M}$ histones were added to the reaction mixture. (A) Autoradiography of nuclear extracts showing methylation. The level of methylation on a $16-\mathrm{kD}$ protein was measured with densitometer from three individual experiments and plotted below. Error bars indicate \pm SD. (B) $20 \mu \mathrm{M}$ of histones were added to the methylation assay and autoradiography was performed. ylating a $16-\mathrm{kD}$ protein in the nuclear fraction can also bind to histones. However, unlike cytosolic fraction which can methylate exogenously added histones (Kwon et al., 2004), nuclear methyltransferases did not appear to methylate histones as no bands were present around $16 \mathrm{kD}$ (Figure 1 , day $1 \mathrm{~N}+\mathrm{H}$ ).

To further study the pattern of methylation during the regeneration process, we obtained nuclear extracts from regenerating rat liver at various time points post hepatectomy and subjected to the in vitro methylation assay. Interestingly, as shown in Figure $2 \mathrm{~A}$, methylation of a $16-\mathrm{kD}$ protein only occurred 1 day following hepatectomy. After 3 days, methylation of this band was not detected. To see if methylation events occurring during the course of regenerating period were affected by histones, bulk histone were added to the reaction mixture and the methylation events were monitored (Figure 2B). However, even at later time points, methylation of nuclear proteins did not appeared to be affected by added histones. Variations in the methylation levels of nuclear proteins other than a $16-\mathrm{kD}$ protein including $70-\mathrm{kD}, 34-\mathrm{kD}$, $24-k D, 18-k D$ and $7-k D$ proteins in these particular gels were found to arise from individual variations after three independent experiments.

The transient nature of methylation in the $16-\mathrm{kD}$ protein following hepatectomy suggests that a specific nuclear methyltransferase activity is highest in the early stage of liver regeneration where DNA replication and gene transcription leading to cell proliferation and differentiaion begin to start. Alternatively, the 16$\mathrm{kD}$ protein would be expressed in increased amounts in the early stage of liver regeneration and need methylation for its optimal function. Either way, activation of the $16-\mathrm{kD}$ methylation appeared to precede cell proliferation leading to liver regeneration. Therefore, the characterization and identification of the methyltransferases and the $16-\mathrm{kD}$ protein will aid our understanding of the role of methylation in the signaling process resulting in the liver regeneration.

\section{Methylation of a 16-kD protein is inhibited by histone subtypes tested}

Since bulk histone used as an inhibitor of methylation in our assay are mixtures of various subtypes, we next determined the identity of histones responsible for inhibiting methylation of a $16-\mathrm{kD}$ protein. Figure 3 shows that methylation of a $16-\mathrm{kD}$ protein was completely inhibited by S-adenosyl homocysteine (SAH) (Figure 3A, lane 2), a well known inhibitor of methyltransferases (Gu et al., 1999). Addition of bovine serum albumin (BSA) seemed not to affect the methylation (Figure $3 \mathrm{~A}$, lane 3 ). Addition of bulk histone (Figure 3A, lane 4, H2AS) completely inhibited the methylation of a $16-\mathrm{kD}$ protein similar to that shown in Figure 1 and 2. When individual isoforms 
A

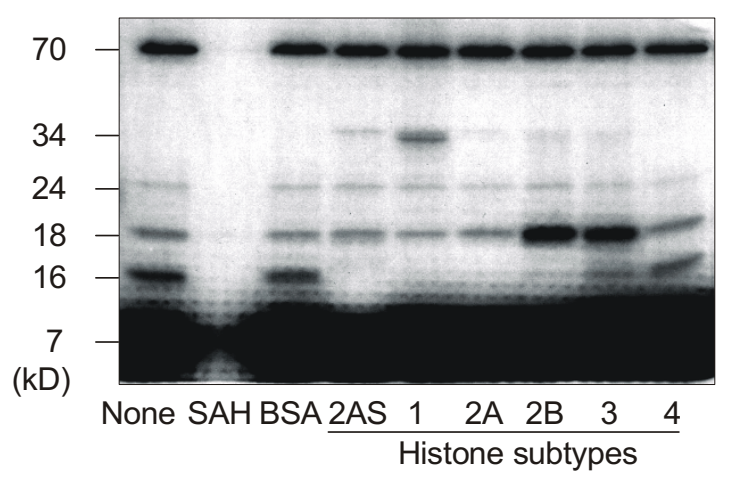

B
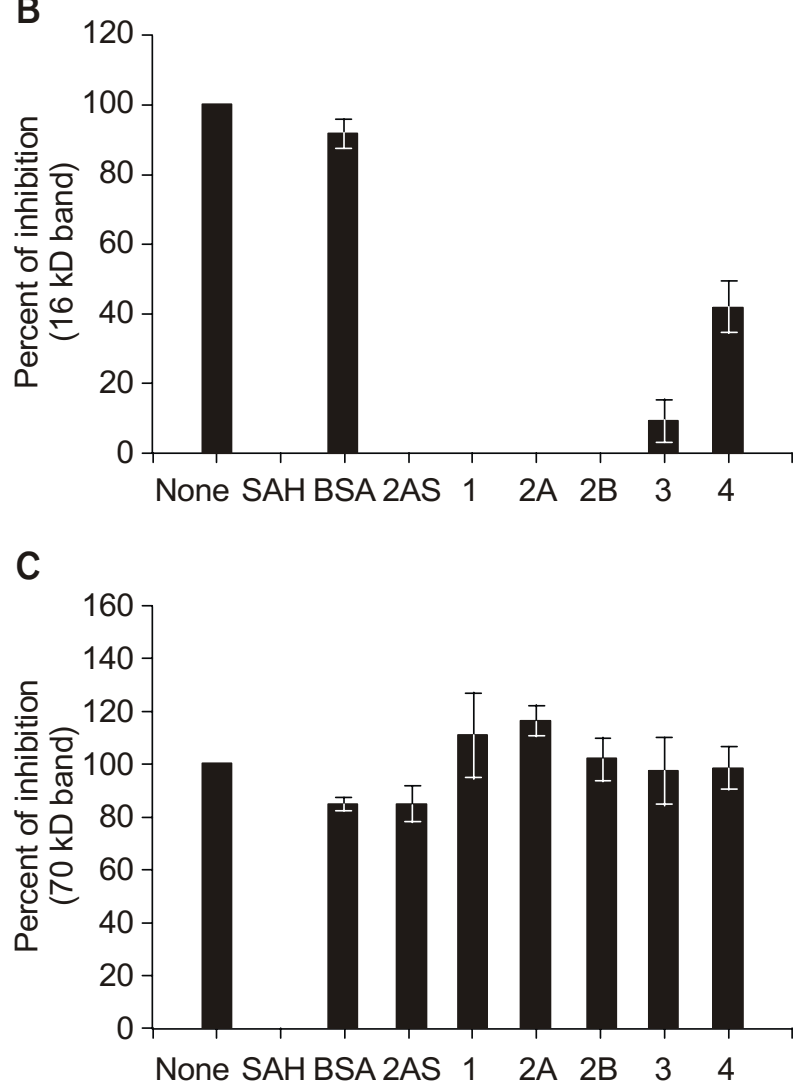

Figure 3. Effects of individual histone subtypes on the methylation of a $16-k D$ protein. (A) Nuclear extracts prepared from day 1 liver following hepatectomy were used for methylatioin assay in the presence of $20 \mu \mathrm{M}$ of bulk histone (H2AS), or individual subtypes of histones, $\mathrm{H} 1, \mathrm{H} 2 \mathrm{~A}, \mathrm{H} 2 \mathrm{~B}, \mathrm{H} 3$, or $\mathrm{H} 4$ (lane 4-9). Lane 1, none, indicates no exogenously added proteins. Addition of $0.8 \mathrm{mM} \mathrm{SAH}$, an inhibitor of methyltransferases, completely inhibited methylation of a $16 \mathrm{kD}$ protein (lane2). $20 \mu \mathrm{M}$ BSA (bovine serum albumin), added as a negative control (lane 3 ), resulted in slight reduction of methylation in the $16-k D$ protein in this blot, however, it was not statistically significant when data are averaged from three individual experiments as shown in a bar graph in (B). (B) The bands of a $16-\mathrm{kD}$ protein or a 70-kD protein from three different experiments were measured using densitometer and their averages were calculated as a percentage as compared to the control value. Error bars indicate \pm SD. of histones were added to the reaction mixture, the histone subclasses $1,2 \mathrm{~A}$ or $2 \mathrm{~B}$ showed near complete inhibition of the $16-\mathrm{kD}$ protein methylation while histones 3 and 4 showed partial inhibition of the methylation (Figure 3A, lane 5-9). Inhibition of the $16-k D$ protein methylation by histones was more noticeable when the percent density change of a $16-k D$ protein was averaged from three different experiments and plotted as a bar graph (Figure 3B). Among the subtypes of histones tested, histone $\mathrm{H} 4$ was the weakest inhibitor for competing with a $16-\mathrm{kD}$ protein (showing up to $60 \%$ inhibition). H3 showed slightly better inhibition than $\mathrm{H} 4$, but failed to inhibit methylation of a $16-\mathrm{kD}$ protein completely (up to $90 \%$ ). In contrast, methylation of a $70-k D, 24-k D, 18-k D$ or $7-k D$ protein was not affected significantly by addition of any histone subtypes tested (Figure $3 \mathrm{~A}$ and $\mathrm{C}$ ). These data demonstrate that the $16-\mathrm{kD}$ protein and all the subclasses of histones are recognized by a same methyltransferase, but do not share a common methylation motif or a significant homology. Rather, histones are likely to act as allosteric inhibitors for the methyltransferase. Of note, addition of histones, particulary $H 1$, resulted in methylation of a new band running around $34 \mathrm{kD}$. Likewise, addition of histones $2 \mathrm{~B}$ and 3 generated more intense $18-\mathrm{kD}$ methylation (3-4 fold higher than when its absence). Identity of the band is not clear at present, however, given the molecular weight of the $18-\mathrm{kD}$ proteins, it can be speculated to be one of the histone subtypes tested.

To further determine the specificity of methyltransferase reaction, we added known methyl donors to prevent methylation reaction between nuclear methyltransferases and a 16-kD protein (Figure 4). Among the proteins tested, cytochrome $\mathrm{C}$ (cyt), and alcohol dehydrogenase $(A D H)$ specifically inhibited the methylation of a $16-\mathrm{kD}$ protein, and, interestingly, alcohol dehydrogenase inhibited the $70-\mathrm{kD}$ methylation as well. By contrast, myelin basic protein (MBP), carbonic anhydrase (Car), $\chi$ globulin (Glo), and $\alpha$ - lactalbumin (Lac) minimally affected the methylation of a 16-kD protein (Figure 4, lane 3, 6, 7, 8). Taken together, these data suggest that methyltransferases responsible for methylating a $16-\mathrm{kD}$ protein possess distinct substrate specificity.

\section{A methylated $16-\mathrm{kD}$ protein is resistant to alkali/ acid-induced demethylation but sensitive to GTP} We next determined if methylation of a $16-k D$ protein occurs through carboxyl O-methylesterification on aspartate or glutamate residues, or C-terminal farnesylated cysteine carboxyl methylation. Methyl-incorporation through ester linkages is alkali-labile (Tan et al., 1991), and methylation at the carboxyl group of C-terminal farnesylated cysteine carboxyl methylation should be stimulated by GTP analogs such as 
A

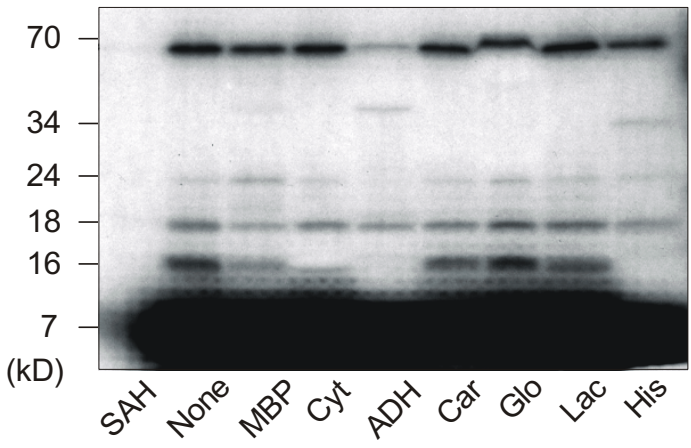

B

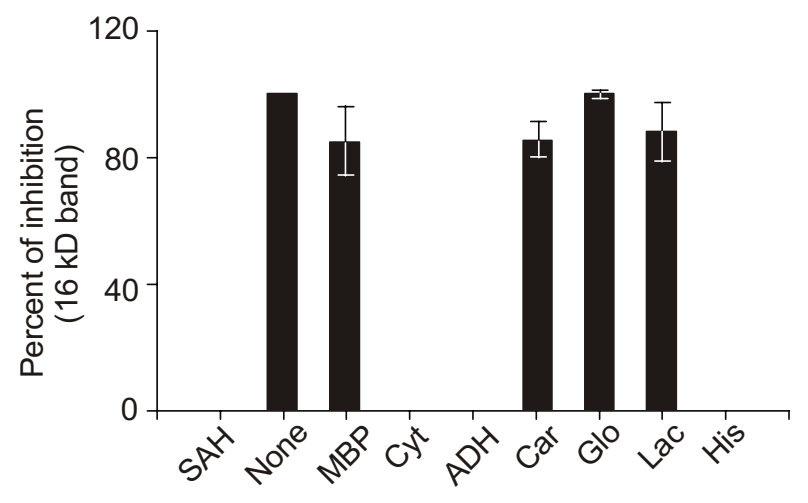

C

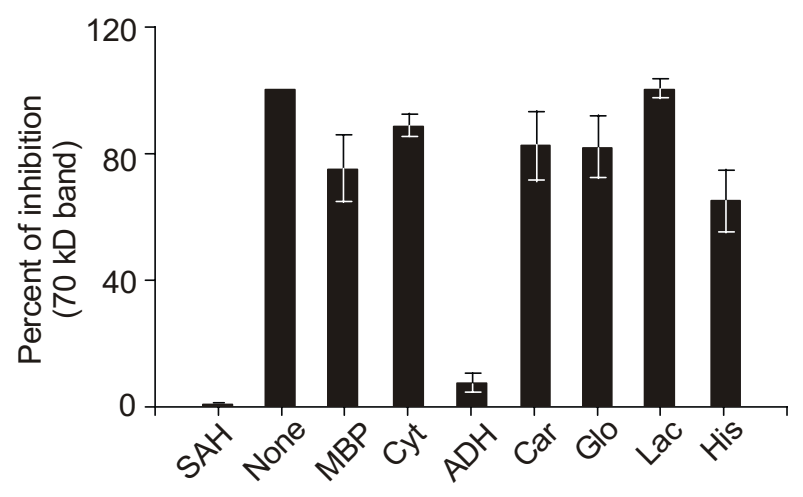

Figure 4. Effects of various proteins on the methylation of a $16-\mathrm{kD}$ protein. (A) Day 1 liver nuclear extracts were subjected to the methylation assay in the presence of $20 \mu \mathrm{M}$ myelin basic protein (MBP, lane 3), cytochrome C (Cyt, lane 4), alcohol dehydrogenase (ADH, lane 5), carbonic anhydrase (Car, lane 6$), \chi$ globulin (Glo, lane 7), $\alpha$-lactalbumin (Lac, lane 8), or bulk histones (His, lane 9). S-adenosyl homocysteine (SAH, lane 1) was added as a transmethylation inhibitor. Reactions were subjected to SDS-PAGE and autoradiography. (B) The intensities of a $16-\mathrm{kD}$ protein and $70-\mathrm{kD}$ protein were measured from three different experiments and their averages were calculated as a percentage as compared to the control value. Error bars indicate $\pm S D$.

GTPYS. Proteins containing C-terminal farnesylated cysteine may indeed belong to the family of small
A
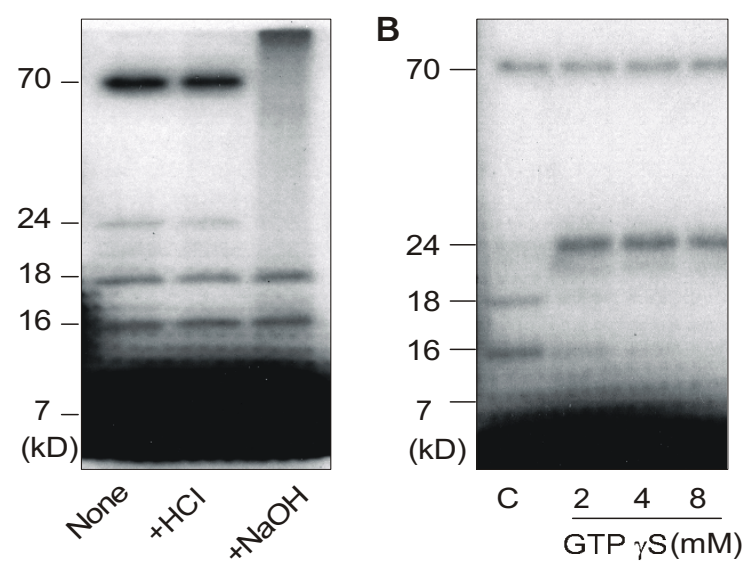

Figure 5. Effects of acid, alkali, and GTP $\gamma$ S in the methylation of nuclear proteins. (A) Nuclear extracts subjected to methylation assay were treated wih either $1 \mathrm{~N} \mathrm{HCl}$ or $\mathrm{NaOH}$. In (B) 2-8 mM of GTPyS was added to the methylation assay. The resulting samples were subjected to SDS-PAGE and autoradiography.

molecular G proteins (Backlund, 1992). Thus, if methylation of a protein increases by GTP $\gamma$ S, it will be likely to function as a $G$ protein itself or an intermediate. When nuclear extracts were treated with $\mathrm{HCl}$ (pH 3-4), no significant changes were detected in any of the methylated proteins (Figure 5A lane 2). Intriguingly, when $\mathrm{pH}$ was lowered further below 2, only the 18-kD methylation was affected and disappeared completely, strongly indicating the presence of potential acid lability in strong acid conditions in certain methylations (data not shown). In contrast, treatment of nuclear extracts with $\mathrm{NaOH}$ resulted in disappearance of bands running at $70 \mathrm{kD}$ and $24 \mathrm{kD}$ while left no changes in the rest of bands including a $16-k D$ protein. These data suggest that the methyl linkage of $70-k D$ and $24-k D$ proteins were likely formed via carboxyl O-methylesterification while that of $16-\mathrm{kD}$ and $18-\mathrm{kD}$ proteins do not involve ester linkage.

When nuclear extracts were treated with GTP $\gamma S$, methylation of both $16-\mathrm{kD}$ and $18-\mathrm{kD}$ proteins was significantly inhibited. As shown in Figure $5 \mathrm{~B}$, addition of GTP $\gamma$, which activates small molecular weight $G$ proteins, inhibited methylation of $16-k D$ and $18-k D$ proteins in a dose dependent manner (Figure 5B). These data suggest that activation of $G$ protein negatively regulates the activity of methyltransferases responsible for methylation of $16-\mathrm{kD}$ and $18-\mathrm{kD}$ proteins. These data are in contrast to those observed in the case of $\mathrm{C}$-terminal farnesylated cysteine carboxyl methylation stimulated by unhydrolyzable GTP and further indicate that small molecular weight $G$ proteins function as a regulator of methylation. In contrast to $16-\mathrm{kD}$ and $18-\mathrm{kD}$ proteins, a $24-\mathrm{kD}$ protein 
showed an enhanced methylation upon addition of GTP $\gamma$ S, suggesting that methyl group of a $24-k D$ protein was likely to be incorporated to the $\mathrm{C}$-terminal farnesylated cysteine. By contrast, a $70-\mathrm{kD}$ protein (Figure $5 \mathrm{~A}$ ), whose methylation was significantly labile in alkaline condition, did not show any changes in the level of methylation by GTP (Figure 5B).

Taken together, our data suggest that the nature of methylation process of individual nuclear proteins shows specificity during the course of liver regeneration. These data also demonstrate that more than one methyltransferases function to methylate nuclear proteins and each reaction is likely performed on distinct amino acids, such as arginine, lysine, aspartates, glutamates, or cysteine. The resistance of a $70-\mathrm{kD}$ protein to alkali and GTP suggests that its methylation is most likely to be carboxyl O-methylesters in the side chains of aspartates or glutamates. The $24 \mathrm{kD}$ methylation was alkali-labile and stimulated by GTP, indicating it involves a carboxyl methyl-esterification on C-terminal cysteinyl residues. On the other hand, the methyl groups in the $18-\mathrm{kD}, 16-\mathrm{kD}$ and $7-\mathrm{kD}$ proteins were stable at $\mathrm{pH} 10-11\left(37^{\circ} \mathrm{C}\right.$ for $\left.30 \mathrm{~min}\right)$, indicating that neither carboxyl methyl-esterification on isoaspartyl residues nor C-terminal cysteinyl residues were involved, but rather methylations on arginyl or lysyl residue may be operational. Importantly, the lability of the 18-kD methylation in strong acid condition could provide a new approach to differentiate among different amino acid methylations.

\section{Discussion}

Covalent modification of proteins such as phosphorylation, acetylation, ubiquitination, and methylation is central for fundamental cellular processes from DNA replication to cell proliferation and differentiation. The level of modification in a given cell is determined by a balance between forward and reverse reactions carried out by specific enzymes. While protein phosphorylation, acetylation, and ubiquitination events are widely studied, protein methylation events have only recently been acknowledged in spite of the discovery of cellular methyltransferases (PRMTs) and their substrates several decades ago. Histones are one such substrate which can undergo methylation and regulate gene transcription. However, it has been a great question how methylation reaction is terminated. In the case of phosphorylation and acetylation, phosphatases and deacetylases were identified to regulate the level of modification. However, enzymes responsible for demethylation of proteins have not been identified up to now (Bannister et al., 2002). Only recently a nuclear deiminase called "peptidyl arginine deiminase 4 (PADI4)" is identified as an enzyme capable of preventing methylation by converting arginine residues into citrulline. An example was shown in the regulation of histone $\mathrm{H} 3$ where methylation of arginine residues $\mathrm{R} 2, \mathrm{R} 8, \mathrm{R} 17$, and $\mathrm{R} 26$ could be specifically deiminated (Cuthbert et al., 2004). Therefore, methylation events are also subject to tight regulation which can be turned on by cellular stimuli and turned off when it is no longer needed.

Our data shown here together with the previous reports strongly demonstrate that proliferating hepatocytes undergo time-dependent activation of methyltransferase activity. Methyltransferase activity is present in both fractions of cells; cytosol and nucleus, and shown to regulate methylation of cytosolic and nuclear proteins with distinct specificity and time dependency. First of all, methylation of proteins in the cytosol was only detected in a 20-kD protein and persisted up to 7 days following hepatectomy (Kwon et al., 2004). In contrast, nuclear fraction showed basal level of methyltransferase activities to methylate at least four distinct bands $(7,18,24,70$ kD; Figure 1B). Upon hepatectomy, none of these bands seemed to undergo methylation or demethylation, but a distinct new band running at $16-\mathrm{kD}$ protein appeared to be heavily methylated in vitro (Figure $1 \mathrm{~B}$ ). Methylation of the $16-\mathrm{kD}$ protein is only observed 1 day following hepatectomy, indicating that in contrast to the cytosolic methyltransferases, the nuclear methyltransferase responsible for methylating a $16-\mathrm{kD}$ protein in regenerating liver shows transient early activation following hepatectomy, or alternatively level of the nuclear 16-kD methylation increases only in the initial stage of liver regeneration. These data suggest that distinct methyltransferases, showing specificity against their substrates in the specific location, may reside in the cytosol and nucleus. How these enzymes become activated or whether the changes of methylation in the $16-\mathrm{kD}$ protein contribute to the liver regeneration is not clear at present. However, early activation of nuclear methyltransferases immediately after proliferating stimuli allows us to speculate that activation of specific methyltransferases and subsequent methylation may play a role in turning on or off specific genes culminating in cell proliferation as shown for the case of histones (Nielsen et al., 2001).

Interestingly, inhibition of the methylation of a $16-k D$ protein by histones made us question if this protein may indeed be histones. However, it appeared not to be the case. Rather histones function as an allosteric inhibitor to prevent methylation of a $16-\mathrm{kD}$ protein, since methyltransferases for a $16-k D$ protein did not cause methylation of exogenously added histones. Interestingly, unlike cytosolic methyltransferases which can be competed out only by alcohol dehydrogenases, nuclear methyltransferases for a $16-k D$ protein were able to be competed out by both 
alcohol dehydrogenases and cytochrome C. And alcohol dehydrogenase also inhibited the 70-kD methylation. These data reinforce the distinct nature of methyltransferases in the cytosol and the nucleus. Addition of alcohol dehydrogenase not only inhibited methylation of a $16-\mathrm{kD}$ protein but also made a new band running at $40 \mathrm{kD}$ (Figure $4 \mathrm{~A}$ ). Since alcohol dehydrogenases themselves migrate around $150 \mathrm{kD}$, it could possibly be suggested that added alcohol dehydrogenases became methylated by the nuclear methyltransferases and was thereby facilitated to be degraded. More interesting phenomenon is the fact that the methyl group of a $16 \mathrm{kD}$-protein is neither on the carboxyl group nor on the farnesylated cysteine. And the fact that added GTP $\gamma$, which activates $G$ proteins through preventing dephosphorylation of $\gamma$ phospho group bound on $G$ proteins (Sasaki and Hasegawa-Sasaki, 1987), resulted in disappearance of the $16-\mathrm{kD}$ methylation suggested that a $16-k D$ protein is neither methylated on farnesyl cysteines nor GTP-binding proteins. Rather, activation of GTP-binding proteins tends to suppress the $16-\mathrm{kD}$ methylation. Interestingly, addition of GTP $\gamma S$ enhanced methylation of a $24-\mathrm{kD}$ protein, suggesting that this band may be a GTP-binding protein. Alternatively, activated $G$ proteins in the nucleus may in turn cause activation of methyltransferases to methylate the $24-\mathrm{kD}$ protein. Further study is under way to identify the nature of bands affected by GTP- binding proteins.

Many of the substrates of protein arginine methyltransferases (PRMTs) such as hnRNP A1 ( $M_{r}$ $\sim 34,000$ ) (Williams et al., 1985) and A2 protein $\left(M_{\mathrm{r}}\right.$ $\sim 34,000)$ (Nichols et al., 2000), nucleolin $\left(M_{\mathrm{r}}\right.$ $\sim 100,000$ ) (Srivastava and Pollard, 1999), fibrillarin $\left(M_{\mathrm{r}} \sim 34,000\right)$ (Lischwe et al., 1985), HMG chromosomal protein $\left(M_{\mathrm{r}} \sim 9,200 \mathrm{kDa}\right)$ (Boumba et al., 1993) and histones (Wallwork et al., 1977), have been shown to be localized in the nucleoplasm, nucleoli or chromosome (Boffa et al., 1979; Lischwe et al., 1985), indicating their regulatory roles in gene expression (Dreyfuss et al., 1993; Caceres et al., 1994) or DNA replication (Planck and Wilson, 1980; Williams et al., 1985; Kumar et al., 1986; Cobianchi et al., 1988). Studies are in the progress to determine if the methylated proteins shown in our study co-migrate with PRMT substrates described above.

In our study, methylation of both cytosolic and nuclear proteins was detected in the absence of pretreatment of cells with endogenous methyltransferase inhibitors, such as adenosine dialdehyde. However, previous reports using human lymphoblastoid cells showed that methylations of proteins between 29 and $90 \mathrm{kDa}$ were observed only when cells were pretreated with adenosine dialdehyde to obtain hypomethylated state of endogenous substrates ( $\mathrm{Li}$ et al., 1998). Similarly, RNase treatment of RAT1 cell extracts resulted in methylation of hnRNP A1 and a series of cellular proteins running between 34 - and 55-kD (Frankel and Clarke, 1999). These data suggested that substrates were constantly associated with RNAs, which inhibited the access of these proteins to methyltransferases. Since our study indicates that the nuclear $16-\mathrm{kD}$ protein became methylated in the absence of pretreatment, and its in vitro methylation was remarkably enhanced by proliferative stimuli only in the beginning of rat liver regeneration, the protein may represent the true physiologic substrates undergoing methylation and thus, be involved in early signaling events leading to cell proliferation.

\section{Acknowledgement}

This work was supported by the research grant from Ministry of Education, Republic of Korea (1998-001F00034).

\section{References}

Backlund PS, Jr. GTP-stimulated carboxyl methylation of a soluble form of the GTP-binding protein $\mathrm{G} 25 \mathrm{~K}$ in brain. $\mathrm{J}$ Biol Chem 1992;267:18432-9

Bannister AJ, Schneider R, Kouzarides T. Histone methylation: Dynamic or static? Cell 2002;109:801-6

Boffa LC, Sterner R, Vidali G, Allfrey VG. Post-synthetic modifications of nuclear proteins. High mobility group proteins are methylated. Biochem Biophys Res Commun 1979;89: $1322-7$

Boumba VA, Tsolas O, Choli-Papadopoulou D, Seferiadis K. Isolation by a new method and sequence analysis of chromosomal HMG-17 protein from porcine thymus. Arch Biochem Biophys 1993;303:436-42

Bradford MM. A rapid and sensitive method for the quantitation of microgram quantities of protein utilizing the principle of protein-dye binding. Anal Biochem 1976;72:248-54

Caceres JF, Stamm S, Helfman DM, Krainer AR. Regulation of alternative splicing in vivo by overexpression of antagonistic splicing factors. Science 1994;265:1706-9

Cobianchi F, Karpe R, Williams KR, Notario V, Wilson SH. Mammalian heterogeneous nuclear ribonucleoprotein complex protein A1. Large scale overproduction in Escherichia coli and cooperative binding to single-stranded nucleic acids. J Biol Chem 1988;263:1063-71

Cuthbert GL, Daujat S, Snowden AW, Erdjument-Bromage $H$, Hagiwara $T$, Yamada M, Schneider R, Gregory PD, Tempst $\mathrm{P}$, Bannister AJ, Kouzarides T. Histone deimination antagonizes arginine methylation. Cell 2004;118:545-53

Dreyfuss G, Matubis MJ, Pino/Roma S, Burd CG. HnRNP proteins and the biogenesis of mRNA. Ann Rev Biochem 1993;62:289-321 
Duerre JA, Wallwork JC, Quick DP, Ford KM. In vitro studies on the methylation of histones in rat brain nuclei. J Biol Chem 1977;252:5981-5

Frankel A, Clarke S. RNase treatment of yeast and mammalian cell extracts affects in vitro substrate methylation by type I protein arginine N-methyltransferases. Biochem Biophys Res Comm 1999;259:391-400

Gary JD, Lin WJ, Yang MC, Herschman HR, Clarke S. The predominant protein-arginine methyltransferase from Saccharomyces cerevisiae. J Biol Chem 1996;271:12585-94

Gu H, Park SH, Park GH, Lim IK, Lee HW, Paik WK, Kim $S$. Identification of highly methylated arginine residues in an endogenous $20-\mathrm{kDa}$ polypeptide in cancer cells. Life Sci $1999 ; 65: 737-45$

Kumar A, Williams KR, Szer W. Purification and domain structure of core hnRNP proteins $A 1$ and $A 2$ and their relationship to single-stranded DNA-binding proteins. J Biol Chem 1986;261:11266-73

Kwon S-Y, Kim S, Lee K, Kim TJ, Lee S-H, Lee K-M, Park $\mathrm{GH}$. Increased methylation of the cytosolic $20-\mathrm{kD}$ protein is accompanied by liver regeneration in a hepatectomized rat. Exp Mol Med 2004;36:85-92

Laemmli VK. Cleavage of structural proteins during the assembly of the head of bacteriophage T4. Nature 1970;227: 680-5

Li C, Ai L-S, Lin C-H, Hsieh M, Li Y-C, Li S-Y. Protein $\mathrm{N}$-Arginine methylation in adenosine dialdehyde-treated lymphoblastoid cells. Arch Biochem Biophys 1998;351:53-9

Lischwe MA, Cook RG, Ahn YS, Yeoman LC, Busch H. Clustering of glycine and $N^{G}, N^{G}$-dimethylarginine in nucleolar protein C23. Biochemistry 1985;24:6025-8

McBride AE, Silver PA. State of the Arg:protein methylation at arginine comes of age. Cell 2001;106:5-8

Nichols RC, Wang XW, Tang J, Hamilton BJ, High FA, Herschman HR, Rigby WFC. The RGG domain in hnRNP A2 affects subcellular localization. Exp Cell Res 2000;256: 522-32

Nielsen SJ, Schneider R, Bauer UM, Bannister AJ, Morison $A$, O'Carroll $D$, Firestein $R$, Cleary $M$, Jenuwein $T$, Herrera $\mathrm{RE}$, Kouzarides $\mathrm{T}$. $\mathrm{Rb}$ targets histone $\mathrm{H} 3$ methylation and HP1 to promoters. Nature 2001;412:561-5
Paik WK, Kim S. Enzymology of protein methylation. In: Protein methylation: Series of Monographs, Vol. 1 (Paik WK, Kim S eds), 1980, 112-41, John Wiley and Sons, New York, NY

Paik WK, Kim S, Ezirike J, Morries HP. S-adenosylmethionine:protein methyltransferases in hepatomas. Cancer Res 1975;35:1159-63

Park SH, Park GH, Gu H, Hwang W-I, Lim IK, Paik WK, Kim S. Heterogeneous nuclear RNP protein A1-arginine methylation during HCT-48 cell cycle. Biochem Mol Biol Int 1997;42:657-66

Planck SR, Wilson SH. Studies on the structure of mouse helix-destabilizing protein-1. DNA binding and controlled proteolysis with trypsin. J Biol Chem 1986;255:11547-56

Sasaki T, Hasegawa-Sasaki H. Activation of polyphosphoinositide phospholipase C by guanosine 5'-O-(3-thio)triphosphate and fluoroaluminate in membranes prepared from a human $\mathrm{T}$ cell leukemia line, JURKAT. FEBS Lett 1987; 218:87-92

Spector DL, Goldman RD, Leinwand LA. Preparation of nuclei from tissue and suspension cultures. In: Cells: Culture and biochemical analysis of cells (Spector DL, Goldman RD, Leinwand LA, eds), 1998, 43.1-43.6, Cold Spring Harbor Laboratory Press, USA

Srivastava M. Pollard HB. Molecular dissection of nucleolin's role in growth and cell proliferation: new insights. The FASEB Journal 1999;13:1911-22

Tan EW, Perez-Sala D, Canada FJ, Rando RR. Identifying the recognition unit for $G$ protein methylation. J Biol Chem 1991;266:10719-22

Wallwork JC, Quick DP, Duerre JA. Properties of soluble rat brain histone lysine methyltransferase. J Biol Chem 1977; 252:5977-80

Waynforth HB, Flecknell PA. Hepatectomy. In Experimental and surgical technique in the rat, 2nd Ed, (Waynforth HB, Flecknell PA, eds), 1992, 241-8, Academic Press Ltd., London

Williams KR, Stone KL, LoPresti MB, Merrill BM, Planck SR. Amino acid sequence of the UP1 calf thymus helixdestabilizing protein and its homology to a analogous protein from mouse myeloma. Proc Natl Acad Sci USA 1985;82: 5666-70 